\title{
Genome size variation in Vicia faba
}

\author{
M. CECCARELLI, S. MINELLI, F. MAGGINI† \& P. G. CIONINI* \\ Dipartimento di Biologia Cellulare e Molecolare, Sezione di Citologia e Genetica Molecolare, Università di Perugia, Via \\ A. Pascoli, 1-06123 Perugia and †Dipartimento di Agrobiologia e Agrochimica, Università della Tuscia, Via S. Camillo de \\ Lellis, 1-01100 Viterbo, Italy
}

Findings obtained using different approaches indicated the occurrence of genomic size variations within $V$. faba. Significant differences in the basic amount of nuclear DNA (up to 34.6 per cent) between 39 local populations collected from the Mediterranean Basin were observed by means of Feulgen/DNA cytophotometry. By contrast, no difference in genome size was found when five commercial varieties were compared. Dot blot hybridization of FokI $V$. faba repeats to genomic DNAs showed up to fourfold differences in the redundancy of these sequences in the nuclear DNA of different accessions. In agreement with the cytophotometric findings, a significant, positive correlation was determined between the DNA contents of populations and the copy numbers of DNA sequences related to FokI repeats. Significant differences between accessions were found in the length of the chromosome complement at metaphase, and these differences were particularly apparent in certain chromosome pairs. A positive correlation was found between the length of the complement and the genome size of the populations. These results are discussed in relation to other data in the literature on intraspecific nuclear DNA changes.

Keywords: DNA cytophotometry, FokI DNA sequences, intraspecific DNA changes, karyometry, repetitive DNA, Vicia faba.

\section{Introduction}

Today, there is a growing consensus of opinion that proliferation or deletion of nuclear DNA sequences does not occur only in the case of divergence and evolution of species. Indeed, many results obtained in different materials have shown that fluid domains, which are capable of rapid quantitative changes, may exist in the genome. These DNA domains, which are generally made up of repeated sequences, possibly occur more commonly, and express their ability to vary more frequently, in plant genomes than in animal genomes (reviewed for plants by Walbot \& Cullis, 1985; Cionini, 1989; Bassi, 1990; Cullis, 1990; Nagl, 1990).

Redundancy variation of DNA sequences may accompany certain developmental processes. It has been suggested that they play a regulatory role in development (Frediani et al., 1994 and references therein). Intraspecific alterations of the basic amount of nuclear DNA may also correlate with differing environmental factors; thus, these alterations have been explained as adaptive (Ceccarelli et al., 1992 and references therein). This view seems to be supported

${ }^{*}$ Correspondence. by results indicating that quantitative changes in nuclear DNA can affect various phenotypic characters at the cellular and organismal level (Ceccarelli et al., 1993 and references therein).

Because they may be of great biological importance and since many of their aspects are poorly understood, the above-mentioned genomic changes deserve thorough investigation. These changes have been shown to occur in many plant species (see Cavallini \& Natali, 1991), but we do not know to what extent they are of common occurrence. The DNA sequences involved in the variations do not seem to be the same in different instances. To quote but two examples, certain medium repeated sequences mainly show redundancy variations in Helianthus annuus (Natali et al., 1993), while quantitative differences in the nuclear DNA between populations of hexaploid Festuca arundinacea are mainly the result of changes in a fraction of highly repeated sequences (Ceccarelli et al., 1992). The chromosomal organization of varying DNA sequences, as well as the mechanism by which intraspecific alterations in genome size and organization are produced and controlled, are almost entirely unknown.

We investigated the nuclear DNA changes in Vicia faba by studying a number of local populations 
collected from the Mediterranean Basin. Results are reported of DNA cytophotometry, karyometry and molecular hybridization experiments using tandemly repeated FokI sequences, already shown to be frequent in the $V$. faba genome (Kato et al., 1984).

\section{Materials and methods}

\section{Plant material}

Seeds of 39 accessions of Vicia faba were kindly provided by the Istituto del Germoplasma, CNR, Bari, Italy. The seeds were washed in tap water and germinated in damp vermiculite under sterile conditions at room temperature in the dark. The main root and shoot apices of the seedlings were fixed in ethanolacetic acid 3:1 (v/v) or in 10 per cent neutral formalin to be used for DNA cytophotometry. Lateral roots to be squashed for karyological analyses were treated with a 0.05 per cent aqueous solution of colchicine (Sigma) for $4 \mathrm{~h}$ at room temperature and fixed in ethanol-acetic acid. The roots of plantlets grown for 15 days in water changed twice a day under the same conditions as above were collected and used for DNA extraction.

\section{Cytophotometry}

Fixed root or shoot apices of seedlings were treated with a 5 per cent aqueous solution of pectinase (Sigma) for $1 \mathrm{~h}$ at $37^{\circ} \mathrm{C}$ and squashed under a coverslip in a drop of 45 per cent acetic acid. The coverslips were removed by the solid $\mathrm{CO}_{2}$ method and the preparations were Feulgen-stained after different hydrolysis durations in $\mathrm{N} \mathrm{HCl}$ at $60^{\circ} \mathrm{C}: 8 \mathrm{~min}$ for those made with material fixed in ethanol-acetic acid and $20 \mathrm{~min}$ for those made with formalin-fixed material. After staining, the slides were subjected to three 10 min washes in $\mathrm{SO}_{2}$ water prior to dehydration and mounting in DPX $(\mathrm{BDH})$. As simultaneous processing was not possible because of the large number of preparations to be analysed, squashes made with the root tips of a single plantlet of Vicia faba cv. Superaguadulce were concurrently stained for each group of slides and used as standards in order to make the results comparable. All notable differences in Feulgen/DNA absorption between preparations observed using the above method of comparison were further checked by analysing preparations that were made again and processed all together. Feulgen/DNA absorptions in individual cell nuclei were measured at the wavelength of $550 \mathrm{~nm}$, using a Leitz MPV 3 microscope photometer equipped with a mirror scanner and an HP 85 computer. Relative Feulgen/DNA units were converted into picograms of DNA by assuming a 4C DNA content of $53.31 \mathrm{pg}$ (Bennett \& Smith, 1976) in the $V$. faba plant used as a standard.

\section{DNA extraction and probe preparation}

For DNA preparation, about $0.5 \mathrm{~g}$ of fresh root tissue was pulverized with a pestle and mortar in the presence of liquid nitrogen and homogenized in $5 \mathrm{~mL}$ of a pH 8.0 buffer containing $0.1 \mathrm{M}$ Tris, $0.005 \mathrm{M}$ EDTA, $0.5 \mathrm{M}$ $\mathrm{NaCl}$ and $0.01 \mathrm{~m}$ mercaptoethanol. DNA extraction and purification were performed as described by Maggini et al. (1978). The isolated DNA was then suspended in TE buffer $(0.01 \mathrm{M}$ Tris- $\mathrm{HCl} \mathrm{pH} 8.0$ plus $0.001 \mathrm{M}$ EDTA pH 8.0) and stored at $+4^{\circ} \mathrm{C}$.

Tandem arrays of FokI repeats about $300 \mathrm{bp}$ in length were isolated from $V$. faba genomic DNA by digestion with $S a u 3 \mathrm{AI}$ and $R s a I$ restriction endonucleases, and subcloned in pBS- vectors, as described by Maggini et al. (1994).

\section{Dot blot hybridization and calculation of sequence copy numbers}

Replicated samples of 50,25 or $12.5 \mathrm{ng}$ of genomic DNA were suspended in $10 \mu \mathrm{L}$ of TE buffer and applied to a Zeta Probe (Bio-Rad) filter using the Minifold I apparatus (Schleicher and Schuell). On the same filter, $5 \times 10^{8}, 5 \times 10^{9}$, or $5 \times 10^{10}$ copies of FokI sequences were also delivered (FokI dilution spots). The filter was heated at $80^{\circ} \mathrm{C}$ in a vacuum oven for $2 \mathrm{~h}$, prehybridized for $5 \mathrm{~h}$ using $0.2 \mathrm{~mL} \mathrm{~cm}^{-2}$ of hybridization buffer $(5 \times$ SSC, 0.1 per cent $N$-lauroylsarcosine, 0.02 per cent SDS, 1 per cent blocking reagent) and then hybridized for $10 \mathrm{~h}$ using $0.025 \mathrm{~mL} \mathrm{~cm}^{-2}$ of hybridization buffer containing $200 \mathrm{ng}$ of freshly denatured $F o k \mathrm{~L}$ repeats which were labelled with digoxigenin-11-dUTP (Boehringer) using a random primed DNA labelling kit (Promega). After hybridization, filters were washed twice for $5 \mathrm{~min}$ at room temperature with $2 \times \mathrm{SSC}$ containing 0.1 per cent SDS and twice for $15 \mathrm{~min}$ at $65^{\circ} \mathrm{C}$ with $0.1 \times \mathrm{SSC}$ containing 0.1 per cent SDS. Immunological detection of digoxigenin haptens in DNA-DNA hybrids was performed using a DigDNA detection kit (Boehringer). Densitometric scanning of the coloured spots was performed using an LKB 2202 Ultro Scan laser densitometer. The amounts of absorbance of the incident $590 \mathrm{~nm}$ laser beam were then measured with an LKB 2210-062 potentiometric recorder and used to evaluate the relative colour development and therefore the relative amounts of hybridization of the spotted DNA to the labelled probe. The linear regression equation relating the 
natural logarithm of the copy number of FokI repeats in the dilution spots and the natural logarithm of the corresponding densitometric readings was used to calibrate the relationship between the copy number of the sequence probed in the samples of $V$. faba genomic DNA and the amount of absorbance as detected densitometrically.

\section{Karyometry}

For the karyological analyses, the meristems of colchicine-treated and fixed roots were Feulgen-stained and then squashed and mounted as described above. The lengths of metaphase chromosomes were measured on microphotographs. The data obtained were converted into microns by comparison with microphotographs of a micrometric slide.

\section{Results}

\section{Cytophotometry}

All the cytophotometric data given below were obtained from material fixed in ethanol-acetic acid. Comparable results were obtained when formalin-fixed material was used. The mean Feulgen absorptions of early prophases $(=4 C)$ in the root meristems of seedlings obtained from seeds of 39 local populations of $V$. faba and the C-values (the DNA contents of unreplicated haploid chromosome complements) calculated are given in Table 1 . Significant $(P \leq 0.01)$ variations in the basic amount of DNA occur between accessions; considering the most variant values, there is a 34.6 per cent difference between accession no. 111927 from Italy $(\mathrm{C}$-value $=\mathbf{1 0 . 9 4} \mathrm{pg})$ and accession no. 112082 from Morocco $(\mathrm{C}$-value $=14.73 \mathrm{pg}$ ), with the former as standard. On the contrary, the genome sizes of individual plants do not differ significantly within a single accession. Neither do significant differences exist between the DNA contents in the root and shoot meristems of one and the same plant, as proven by comparisons between the respective Feulgen/DNA absorptions made in a number of seedlings belonging to different accessions (data not shown). Significant correlations were not found between the basic DNA contents of the populations and the latitudes, longitudes or altitudes of their places of origin. However, the mean genome size of accessions from Europe $(1 \mathrm{C}=12.81 \pm 0.10 \mathrm{pg})$ differs significantly $(P \leq 0.05)$ from that of accessions from Africa $(1 \mathrm{C}=13.39 \pm 0.11$ $\mathrm{pg}$.

In contrast to the cytophotometric results obtained by studying local populations, Feulgen absorptions of early prophases in the root meristems of seedlings from seeds of five commercial varieties were practically the same, even if the places of origin of the seeds were different (Table 2).

\section{Molecular hybridizations}

Variations in the genome size between populations are also suggested by the results of molecular hybridization experiments. The densitometric absorptions of dot blot filters loaded with genomic DNAs from seedlings obtained by germinating seeds of seven accessions differing in genome size, and hybridized with digoxigenin-labelled FokI $V$. faba repeats, are given in Fig. 1. The sequences probed hybridize to these DNAs to extents that differ significantly. The copy number of FokI sequences in the genome and the percentage of the nuclear DNA that they represent were calculated and are given in Table 3. It can be seen that FokI repeats represent a considerable portion of the genome of $V . f a b a$ (3.09-9.47 per cent in the accessions studied). Their redundancy varies largely between populations; it is four times higher in the accession with the largest genome than in that with the smallest genome $\left(21.51 \times 10^{6}\right.$ copies vs. $5.39 \times 10^{6}$ copies, respectively). These data indicate that repetitive DNA is involved in the variations of genome size between populations, and are in agreement with the cytophotometric findings. Indeed, the positive, significant $(P=0.0127)$ correlation shown in Fig. 2 proves that the redundancy in the nuclear genome of DNA sequences related to the FokI repeats is higher the larger is the basic DNA content of the accessions as determined cytophotometrically (Table 1).

\section{Karyometry}

All local populations studied were found to be diploid $(2 n=2 \mathrm{x}=12)$. The occurrence of supernumerary chromosomes, never reported in $V$. faba, or recurrent aneusomaty in the accessions were not observed.

Table 4 contains data obtained by measuring on microphotographs of metaphase plates the length of each chromosome pair of the complement, which consists of a long, satellited, submetacentric $(M)$ pair and five subtelocentric (S) pairs. The total length of the complement differs significantly between the seven populations differing in genome size. Differences in length, all of which go in the same direction within each accession, occur in all the chromosome pairs. However, by observing the coefficients of variation given in Table 4, it appears that the extents of length 
Table 1 Feulgen absorption of early prophases $(=4 \mathrm{C})$ and DNA content calculated per 1C in 39 local populations of Vicia faba

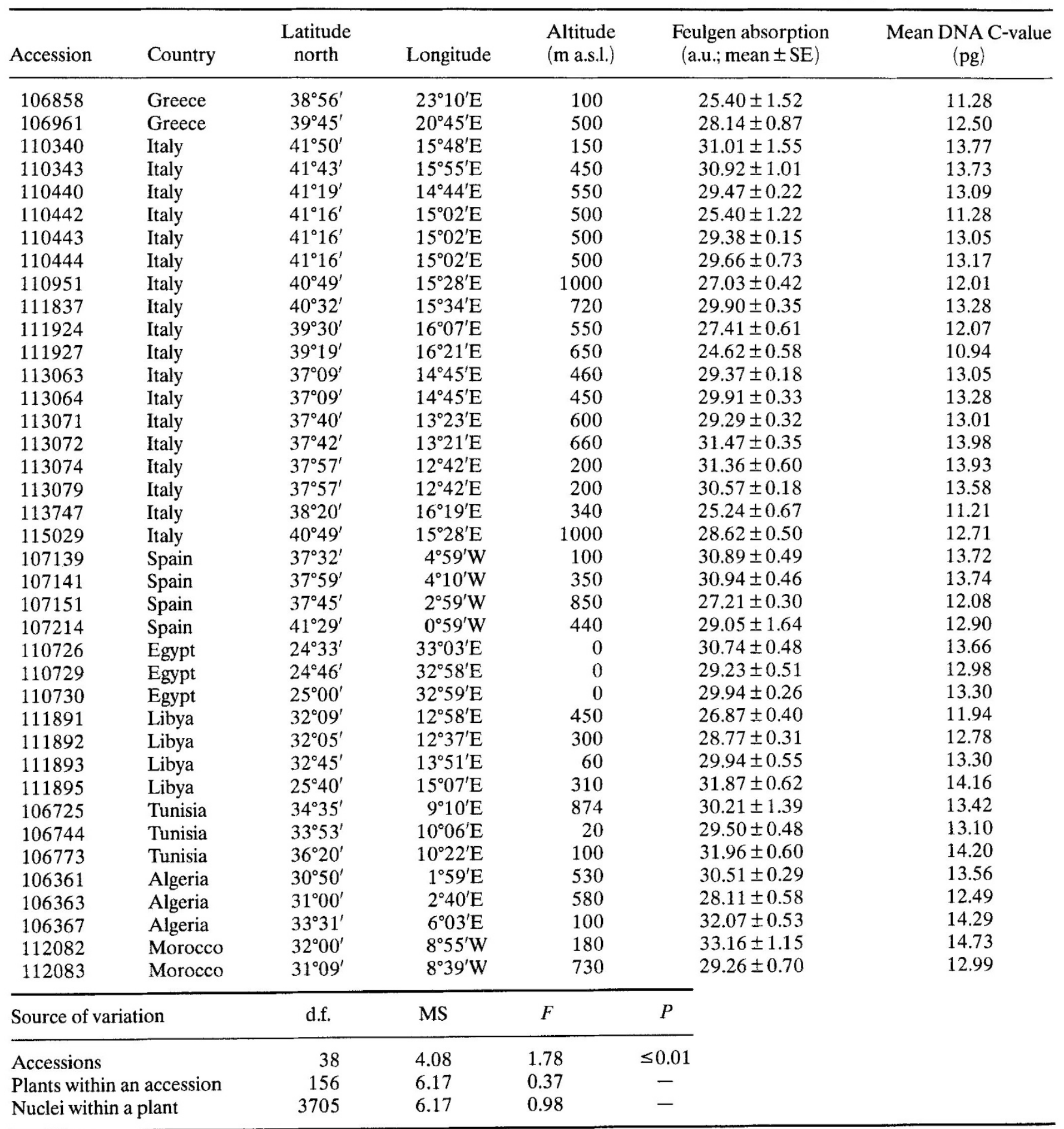

The latitudes and longitudes of the places of origin of the seeds are indicated. Twenty prophases were analysed in the root meristem of each of five seedlings per accession.

differences are not the same in all the chromosomes or chromosome portions. As shown in Fig. 3, a significant $(P=0.013)$ positive correlation exists between the length of the chromosome complement and the basic DNA content of the accessions.

\section{Discussion}

Results obtained using different approaches indicate that changes in the nuclear DNA affecting the C-value differentiate local populations of $V$. faba. Indeed, the 
Table 2 Feulgen absorption of early prophases in five cultivars of $V$. faba

\begin{tabular}{lccc}
\hline Cultivar & Seed provenance & $\begin{array}{c}\text { Feulgen absorption } \\
\text { (a.u.; mean } \pm \text { SE) }\end{array}$ & $\begin{array}{c}\text { Mean DNA } \\
\text { C-value (pg) }\end{array}$ \\
\hline Aprilia & Italy & $29.79 \pm 0.75$ & 13.23 \\
Loreta & Holland & $29.46 \pm 0.47$ & 13.09 \\
Superaguadulce & Morocco & $29.70 \pm 0.33$ & 13.20 \\
Super Set & Morocco & $29.62 \pm 0.63$ & 13.16 \\
Super Simonia & Morocco & $29.41 \pm 0.81$ & 13.07 \\
\hline
\end{tabular}

Twenty prophases were analysed in the root meristem of each of five seedlings per cultivar.

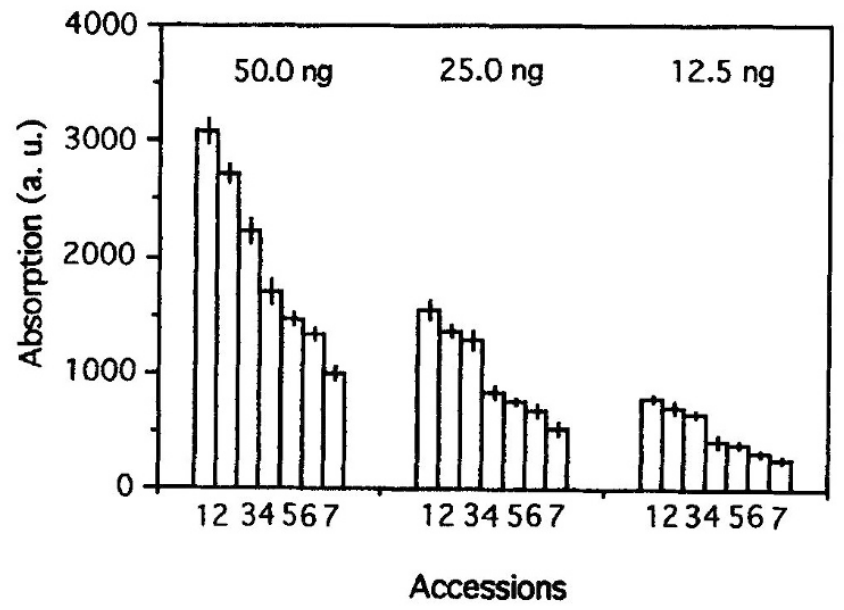

Fig. 1 Densitometric absorptions of dot blot filters loaded with 50.0, 25.0 or $12.5 \mathrm{ng}$ of genomic DNA from the roots of seedlings of seven local populations differing in genome size. 1 , accession no. 112082 from Morocco; 2 , accession no. 110343 from Italy; 3, accession no. 106363 from Algeria; 4, accession no. 106961 from Greece; 5, accession no. 110726 from Egypt; 6, accession no. 111927 from Italy; 7, accession no. 106858 from Greece. The filters were probed with digoxigenin-labelled FokI $V$. faba DNA repeats. Each value is the mean of six repetitions, three for each of two DNA extractions. Confidence intervals are for 99 per cent.

results of Feulgen/DNA cytophotometry, indicating significant differences in the basic DNA content between accessions (Table 1), find confirmation in those of molecular hybridization experiments, showing that tandemly-repeated DNA sequences may be differently represented in the genomes (Fig. 1 and Table 3 ). The existence of intraspecific quantitative variations in the nuclear DNA is further suggested by the results of karyometry, indicating that significant differences between populations may occur in the lengths of their chromosome complements (Table 4). The linear correlations existing between these data (Figs 2 and 3 ) may be regarded as further proof of their reliability. Thus, $V$. faba can be added to the number of species within which variations in genome size and organization have been found (see Cavallini \& Natali, 1991). Our findings are in line with evidence reported for other species which shows that domains that are capable of intraspecific fluidity do exist in the genome of plants (see Introduction). Redundancy variations of sequences in these DNA domains may differentiate even plants within a population, as in Dasypyrum villosum (Frediani et al., 1994) and individuals within a single progeny of homozygous plants, as in Helianthus annuus (Natali et al., 1993).

As well as in D. villosum (Frediani et al., 1994), $H$. annuus (Cavallini et al., 1986; Natali et al., 1993), Festuca arundinacea (Ceccarelli et al., 1992), Pisum sativum (Cavallini et al., 1993) and several other plant species (see Cavallini \& Natali, 1991), repetitive DNA is involved in these genomic changes. Our results point out a particular family of repeated sequences which represent a considerable portion of the nuclear genome of $V$. faba (Table 3). On this point, our findings are in agreement with those of Kato et al. (1984), who calculated that there are $5 \times 10^{6}$ to $5 \times 10^{7}$ copies of FokI elements per diploid genome. However, when comparing the range of variation of these repeats (Table 3) with the differences in DNA content between accessions as assessed cytophotometrically (Table 1), it appears that modulations within other families of DNA sequences must be involved in the creation of the genome size variations within $V$. faba.

The positive correlation between the length of metaphase chromosomes and the basic DNA contents of the accessions (Fig. 3) strongly suggests that quantitative modulations of DNA sequences affect the size of the chromosome complement. Also in other species, changes in the redundancy of repeated DNA sequences were found to correlate with chromosome length variations. It has been suggested that these variations can be due to alterations in the sequence repetitiveness per se, as well as to different rearrange- 
Table 3 Copy number of FokI repeats in the genome and percentage of the genome that they represent in seven local populations of $V$. faba, as calculated from the results of dot DNA blot hybridizations

\begin{tabular}{cccc}
\hline Accession & $\begin{array}{c}\text { DNA C-value } \\
(\mathrm{pg})\end{array}$ & $\begin{array}{c}\text { No. of FokI repeats } \\
\text { per 1C DNA }\left(\times 10^{6}\right)\end{array}$ & $\begin{array}{c}\text { Percentage of the genome } \\
\text { that is FokI repeats }\end{array}$ \\
\hline 112082 & 14.73 & 21.51 & 9.47 \\
110343 & 13.73 & 15.73 & 7.41 \\
106363 & 12.49 & 14.73 & 7.63 \\
106961 & 12.50 & 9.66 & 5.00 \\
110726 & 13.66 & 9.98 & 4.71 \\
111927 & 10.94 & 6.16 & 3.64 \\
106858 & 11.28 & 5.39 & 3.09 \\
\hline
\end{tabular}

DNA C-values are taken from Table 1.

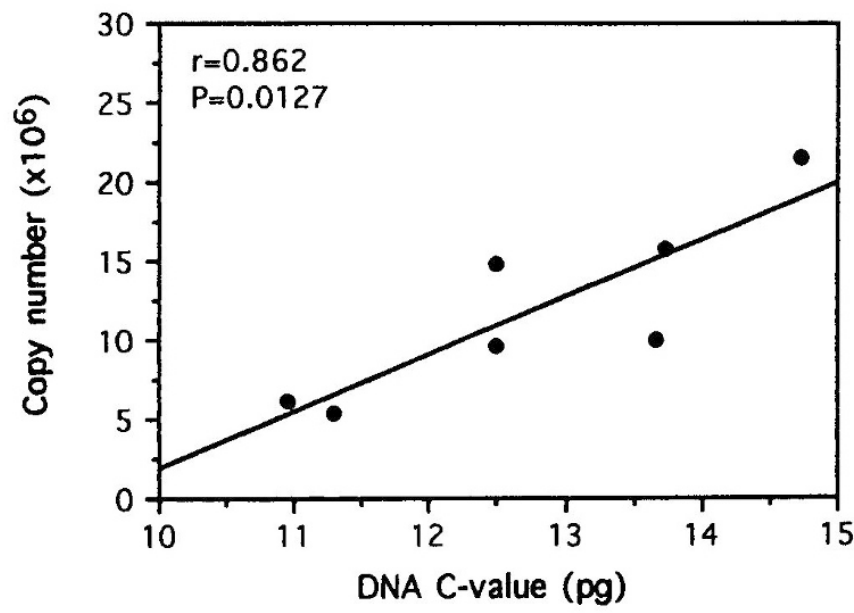

Fig. 2 Correlation between the copy number of sequences related to the FokI DNA repeats in the haploid genome (1C) of the seven local populations in Fig. 1 and their basic DNA content as determined by cytophotometry (Table 1).

ments of the chromatin superstructure that these alterations may induce (see Vogt, 1992 and references therein). Length differences between accessions occur to different extents in different chromosome pairs (Table 4). This suggests that redundancy variations of the same DNA sequences do not take place to the same extent in all the chromosomes and/or that variations concern DNA sequences which are not present in all the chromosomes, as in the case of FokI repeats, which are located only in S pairs (Yakura et al., 1987).

Also in the light of the finding that the genome size of European accessions differs significantly from that of African accessions, it seems proposable that quanti- tative changes in the nuclear genome of $V$. faba play some role in environmental adaptation. Also in other species, this biological role is strongly suggested by the existence of correlations with such environmental factors as latitude or altitude (see Cavallini \& Natali, 1991), temperature (as in $F$. arundinacea; Ceccarelli $e t$ al., 1992) or substratum composition (as in flax; see Cullis \& Cleary, 1986).

In agreement with Bennett \& Smith (1976), our findings show that genome size variations do not occur between commercial varieties of $V$. faba (Table 2), and this result represents a good internal control of the reliability of our cytophotometric data. When environmental adaptation is assumed as the cause of intraspecific variation in the nuclear genome, the lack of this variation between commercial varieties may be explained by the reduction of environmental selective pressure due to a standardized cultivation. Moreover, commercial varieties are genetically stabilized in order to maintain agronomically favourable phenotypical characters.

Quantitative variations in the nuclear genome may play a role in environmental adaptation by affecting developmental dynamics at the cellular and organismal level through nucleotypic effects (Bennett, 1985). Work is in progress to test this possibility in $V$. faba by comparing plant development in different local populations.

\section{Acknowledgements}

The authors are grateful to Centro di Studio per l'Olivicoltura, CNR, Perugia, for laboratory facilities made available in the course of the present investiga- 


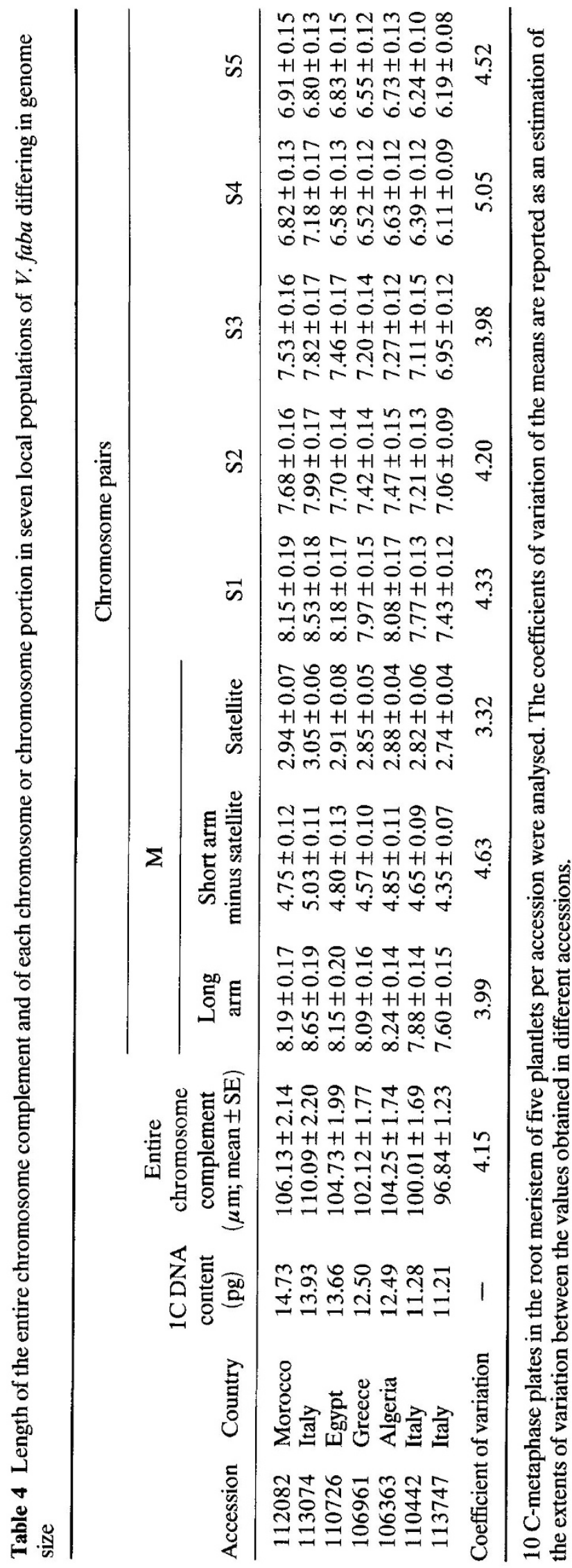

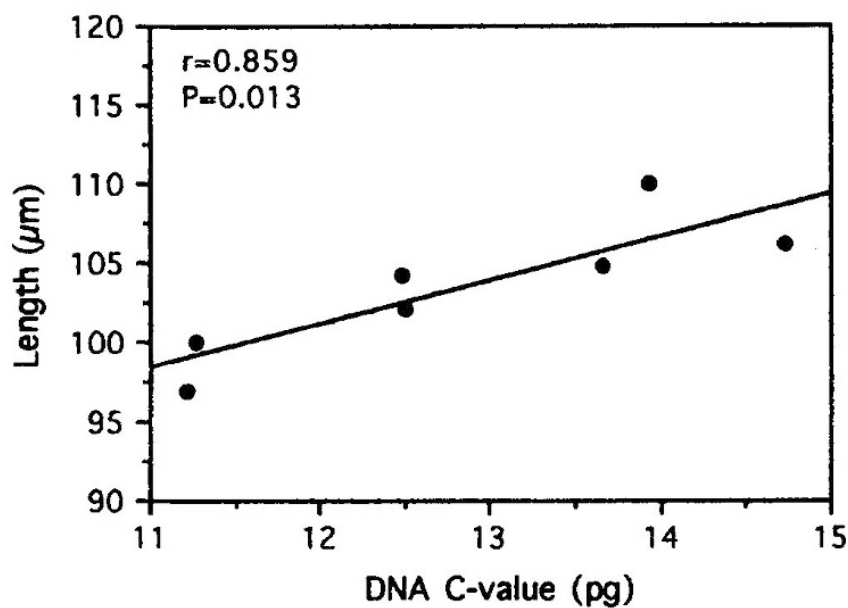

Fig. 3 Correlation between the length of the chromosome complement of the seven local populations in Table 4 and their genome size.

tion. Research supported by the National Research Council, Italy, Special Project RAISA, Subproject no. 2, Paper no. 1934.

\section{References}

BASSI, P. 1990. Quantitative variations of nuclear DNA during plant development: a critical analysis. Biol. Rev., 65, 185-225.

BENNETT, M. D. 1985. Intraspecific variation in DNA amount and the nucleotypic dimension in plant genetics. In: Freeling, M. (ed.) Plant Genetics, pp. 283-302. A. R. Liss, New York.

BENNETT, M. D. AND SMITH, J. B. 1976. Nuclear DNA amounts in Angiosperms. Phil. Trans. R. Soc. B, 274, 227-274.

CAVALLINI, A. AND NATALI, L. 1991. Intraspecific variation of nuclear DNA content in plant species. Caryologia, 44, 93-107.

CAVAlLINI, A., NATALI, L., CIONINI, G. AND GenNaI, D. 1993. Nuclear DNA variability within Pisum sativum (Leguminosae): nucleotypic effects on plant growth. Heredity, 70, 561-565.

CAVALLINI, A., ZOLFINO, C., CIONINI, G., CREMONINI, R., NATALI, L., SASSOLI, O. AND CIONINI, P. G. 1986. Nuclear DNA changes within Helianthus annuus L.: cytophotometric, caryological and biochemical analyses. Theor. Appl. Genet., 73, 20-26.

CECCARELLI, M., FALISTOCCO, E. AND CIONINI, P. G. 1992. Variation of genome size and organization within hexaploid Festuca arundinacea. Theor. Appl. Genet., 83, 273-278.

CECCARELLI, M., MINELLI, S., FALCINELLI, M. AND CIONINI, P. G. 1993. Genome size and plant development in hexaploid Festuca arundinacea. Heredity, 71, 555-560. 
ClONINI, P. G. 1989. Nuclear DNA changes during plant development. Giorn. Bot. Ital., 123, 111-121.

CULlis, C. A. 1990. DNA rearrangements in response to environmental stress. Adv. Genet., 28, 73-97.

CULlis, C. A. AND CLEARY, w. 1986. Rapidly varying DNA sequences in flax. Can. J. Genet. Cytol., 28, 252-259.

FREDIANI, M., COLONNA, N., CREMONINI, R., DE PACE, C., DELRE, V., CACCIA, R. AND CIONINI, P. G. 1994. Redundancy modulation of nuclear DNA sequences in Dasypyrum villosum. Theor. Appl. Genet., 88, 167-174.

KATO, A., YAKURA, K. AND TANIFUJI, S. 1984. Sequence analysis of Vicia faba repeated DNA, the FokI repeat element. Nucl. Acids Res., 12, 37-48.

MAGGINI, F., BARSANTI, P. AND MARAZIA, T. 1978. Individual variation of the nucleolus organizer regions in Allium cepa and $A$. sativum. Chromosoma, 66, 173-183.

MAGGINI, F., D'OVIDIO, R., GELATI, M. T., FREDIANI, M., CREMONINI, R., CECCARElli, M., MINELli, S. AND CIONINI, P. G. 1994. The FokI DNA repeats in the genome of Vicia faba: species-speci- ficity, structure, redundancy modulation, nuclear organization. Genome (in press).

NAGL, w. 1990. Gene amplification and related events. In: Bajaj Y. P. S. (ed.) Biotechnology in Agriculture and Forestry, vol. 11, pp. 153-201. Springer, Berlin.

NATALI, L., CAVALLINI, A., CIONINI, G., SASSOLI, O., CIONINI, P. G. AND DURANTE, M. 1993. Nuclear DNA changes within Helianthus annuus L.: changes within single progenies and their relationships with plant development. Theor. Appl. Genet., 85, 506-512.

VOGT, P. 1992. Code domains in tandem repetitive DNA sequence structures. Chromosoma, 101, 585-589.

WALBOT, v. AND CULLIS, C. A. 1985. Rapid genomic change in higher plants. Ann. Rev. Pl. Physiol., 36, 367-396.

YAKURA, K., KATO, A. AND TANIFUJI, s. 1987. Cytological localization of highly repeated DNA sequences, the FokI sequence family and BamHI sequence families, in Vicia faba chromosomes. Jap. J. Genet., 62, 325-332. 